\title{
GOVERNANSI KORPORAT DAN PRAKTIK MANAJEMEN LABA PADA PERUSAHAAN MANUFAKTUR TERBUKA DI INDONESIA
}

\author{
Ardhya Yudistira Adi Nanggala \\ Universitas Abdurahman Saleh Situbondo \\ Email: dhyananggala@gmail.com
}

\begin{abstract}
This study aims to determine and analyze the effect of corporate governance mechanisms on laboratory management. The governance mechanisms tested are institutional ownership, managerial ownership, the proportion of independent commissioners, the number of commissioners, and the audit committee. Population of this study is manufacturing companies listed on the Stock Exchange from 2015-2017. Sampling was done by purposive sampling method. Research data could be obtained from www.idx.co.id. Based on the results of the study concluded that the corporate governance mechanism consisting of managerial ownership, institutional ownership, the proportion of independent commissioners, the size of the board of commissioners, and the existence of an audit committee had no effect on earnings management.
\end{abstract}

Keywords: Audit Committee, Earning Management, Institusional Ownership, Managerial Ownership

\section{PENDAHULUAN}

Praktik manajemen laba sampai saat ini masih terus diperdebatkan. Hal ini dikarenakan praktik manajemen laba berpotensi menjadi suatu fraud. Pada satu sisi manajemen laba dianggap sebagai praktik yang tidak boleh dilakukan karena akan mengakibatkan informasi yang disampaikan kepada investor menjadi tidak benar (bias). Namun di sisi lain, ada pendapat yang menyatakan bahwa manajemen laba dalam batas tertentu diperlukan untuk mengkomunikasikan semua informasi dari dalam kepada stakeholders.
Manajemen laba merupakan fenomena yang sulit dihindari karena merupakan dampak dari penggunaan accrual basis dalam penyusunan laporan keuangan. Dalam banyak hal, accrual basis dianggap lebih rasional dan adil dibandingkan dengan cash basis. Akan tetapi accrual basis yang ditujukan untuk menjadikan laporan keuangan sesuai dengan fakta dapat sedikit direkayasa sehingga akan mengubah angka laba yang dihasilkan. Banyak penelitian yang membuktikan bahwa pada saat manajer memiliki insentif tertentu, mereka sering berusaha untuk 
mempengaruhi besarnya laba perusahaan dengan cara melakukan rekayasa akrual.

Saat ini praktik manajemen laba merupakan fenomena umum yang terjadi hampir di semua perusahaan. Praktik yang dilakukan untuk mempengaruhi laba dapat dilakukan secara legal maupun ilegal. Praktik legal dalam manajemen artinya dalam usaha mempengaruhi angka laba sesuai atau tidak bertentangan ketentuan pelaporan keuangan yang ditetapkan dalam Prinsip Akuntansi Umum (PABU), khususnya dalam Standar Akuntansi Keuangan. Manajemen secara legal dapat dilakukan dengan cara melakukan perubahan metode akuntansi menggeser periode pengakuan pendapatan dan beban, dan memanfaatkan peluang untuk membuat estimasi akuntansi. Sedangkan manajemen laba secara ilegal adalah manajemen laba yang dilakukan dengan cara-cara yang tidak diperkenankan dilarang oleh PABU, misalnya, dengan melaporkan transaksi-transaksi dan beban secara fiktif dengan cara menambah (mark up) atau mengurangi (down) nilai transaksi, atau bisa juga dengan cara tidak melaporkan sejumlah tertentu sehingga menghasilkan laba pada tingkat tertentu yang dikehendaki.

Kasus manajemen laba yang dilakukan dengan cara ilegal (financial fraud) telah banyak terjadi di sejumlah perusahaan, seperti Enron Corporation, Xerox Corporation, WordCom, Walt Disney Company, dan lainnya. Enron terbukti melakukan manipulasi laba, yaitu melakukan manipulasi eksekutif Enron melalui lembaga auditornya sehingga dapat mendongkrak laba mendekati USD 1 miliar. Xerox Corporation terbukti melakukan manipulasi pendapatan akuntansi, yaitu melakukan manipulasi pembukuan atas pendapatan (revenue) perusahaan sebesar USD 6 miliar. WordCom terbukti melakukan manipulasi pengeluaran akuntansi, yaitu melakukan manipulasi pembukuan senilai USD 4 miliar pada sisi pengeluaran.

$$
\text { Penurunan kualitas laporan }
$$
keuangan merupakan dampak utama yang diakibatkan dari adanya manajemen laba, di samping dampak-dampak lainnya. Setiawati dan Na'im (2000) menyatakan bahwa manajemen laba merupakan salah satu faktor yang dapat mengurangi kredibilitas laporan keuangan. 
Manajemen laba menambah bias dalam laporan keuangan dan dapat mengganggu pemakai laporan keuangan yang mempercayai angka laba hasil rekayasa tersebut sebagai angka laba tanpa rekayasa. Begitu juga menurut Widarto (2004:33) yang menyatakan bahwa dalam pandangan orang awam, manajemen laba dianggap tidak etis, bahkan merupakan bentuk dari manipulasi informasi sehingga menyesatkan.

Adanya fenomena manajemen laba juga memberikan perhatian besar bagi Suwardjono (2005) yang tidak sepakat dengan adanya manajemen laba sebagai bentuk perekayasaan laporan keuangan sehingga tidak mencerminkan kondisi kinerja keuangan sesungguhnya. Suwardjono menyatakan bahwa kemajuan dan reputasi suatu perusahaan harus ditunjukkan dengan kinerja yang sebenarnya bukan sematamata dengan permainan angka-angka. Untuk mengatasi fluktuasi laba tahunan, cara terbaik adalah menerbitkan serangkaian laporan laba rugi tahunan seperti apa adanya dan bukan serangkaian laporan yang diratakan (manajemen laba).

Governansi korporat yang baik (Good Corporate Governance) amat diperlukan sebagai penekan tindakan oportunistik manajemen (Sukamulja, 2004). Mekanisme governansi korporasi merupakan suatu system yang mampu mengendalikan dan mengarahkan kegiatan operasional perusahaan serta pihak-pihak yang terlibat didalamnya, sehingga dapat digunakan untuk menekan terjadinya masalah keagenan (Boediono, 2005). Governansi korporasi memberikan suatu struktur yang memfasilitasi penentuan sasaran-sasaran dari suatu perusahaan, dan sebagai sarana untuk menentukan teknik monitoring kinerja (Deni, Khomsiyah dan Rika, 2004 dalam Ujiyantho dan Pramuka, 2007).

Mekanisme governansi korporasi yang baik dapat dilakukan dengan melalui kepemilikan manajerial, kepemilikan institusional, dewan komisaris, dan komite audit. Penelitian ini bertujuan untuk mengetahui apakah mekanisme governansi korporasi (kepemilikan manajerial, kepemilikan institusional, proporsi dewan komisaris independen, ukuran dewan komisaris, dan komite audit) merupakan penekan praktik manajemen laba.

Berdasarkan uraian tentang praktik earnings management terdapat 
dugaan adanya peran governansi korporasi sebagai penekan praktik earnings management yang dilakukan manajemen. Masalah penelitian dirumuskan sebagai berikut apakah kepemilikan institusional, kepemilikan manajerial, proporsi dewan komisaris independen, jumlah dewan komisaris, dan komite audit berpengaruh terhadap manajemen laba?.

\section{LANDASAN TEORI}

Copeland (1968) seperti yang dikutip oleh Wahyuni (2010) dan Susilowati (2010) mendefinisikan earnings management sebagai some ability to increase or decrease reported net income at will. Ini berarti bahwa earnings management mencakup usaha manajemen untuk memaksimumkan, atau meminimumkan laba (earnings), termasuk perataan laba sesuai dengan keinginan manajemen. Manajemen laba adalah campur tangan dalam proses pelaporan keuangan eksternal dengan tujuan untuk menguntungkan diri sendiri. Manajemen laba merupakan salah satu faktor yang dapat mengurangi kredibilitas laporan keuangan, manajemen laba menambah bias dalam laporan keuangan dan dapat mengganggu pemakai laporan keuangan yang mempercayai angka laba hasil rekayasa tersebut sebagai angka laba tanpa rekayasa (Setiawati dan Na'im, 2000). Manajemen laba merupakan area yang kontroversial dan penting dalam akuntansi keuangan. Beberapa pihak yang berpendapat bahwa manajemen laba merupakan perilaku yang tidak dapat diterima, mempunyai alasan bahwa manajemen laba berarti suatu pengurangan dalam keandalan informasi laporan keuangan. Investor mungkin tdak menerima informasi yang cukup akurat mengenai laba untuk mengevaluasi return dan risiko portofolionya (Ashari dkk, 1994) dalam Assih dan Gudono (2004).

Surifah (1999) memberikan pendapatnya mengenai dampak earnings management terhadap kredibilitas laporan keuangan. Menurut Surifah (1999) earnings management dapat mengurangi kredibilitas laporan keuangan apabila digunakan untuk pengambilan keputusan, karena earnings management merupakan suatu bentuk manipulasi atas laporan keuangan yang menjadi sarana komunikasi antara manajer dan pihak eksternal perusahaan. 


\subsection{Faktor-faktor Manajemen Laba}

Pada umumnya studi tentang earnings management dinyatakan dalam perspektif opportunistics dibandingkan perspektif efisiensi. Perspektif efisiensi manyatakan bahwa manajer melakukan pilihan atas kebijakan akuntansi untuk memberikan informasi yang lebih baik tentang cash flow yang akan datang dan untuk meminimalkan agency cost yang terjadi karena konflik kepentingan antara stakeholder dan manajer (Jiambalvo, 1996 dalam Widyaningdyah, 2001).

Yushita (2010) menjelaskan bahwa ada tiga faktor yang bisa dikaitkan dengan munculnya praktik earnings management yaitu manajemen akrual (accruals management), penerapan kebijakan akuntansi, dan perubahan asset. Faktor akrual berkaitan dengan segala aktivitas yang dapat mempengaruhi aliran kas dan juga keuntungan yang secara pribadi merupakan wewenang dari para manajer (managers discretion).

Faktor kebijakan akuntansi berkaitan dengan keputusan manajer untuk menerapkan suatu kebijaksanaan akuntansi yang wajib diterapkan oleh perusahaan yaitu antara menerapkannya lebih awal dari waktu yang ditetapkan atau menundanya sampai saat berlakunya kebijaksanaan tersebut.

Faktor perubahan asset berkaitan dengan upaya manajer untuk mengganti atau merubah suatu metode akuntansi tertentu diantara sekian banyak metode yang dapat dipilih yang tersedia dan diakui oleh badan akuntansi yang ada.

Riset manajemen laba menyediakan bukti-bukti tentang adanya tindakan manajemen untuk memanipulasi laba. Tujuan riset tersebut biasanya berkaitan dengan pendeteksian apa dan kapan manajemen laba dilakukan. Peneliti umumnya menguji ukuran-ukuran manajemen laba yang bervariasi dan sampel perusahaan dimana motivasi manajemen laba diduga banyak dilakukan.

Beberapa studi menguji manajemen laba sebelum manajemen buyouts. DeAngelo (1988) melaporkan bahwa informasi laba adalah penting untuk penilaian management buyouts dan menghipotesiskan bahwa manajer perusahaan yang buyouts memiliki insentif untuk understate laba. Ia menemukan bukti bahwa earnings management oleh perusahaan yang buyout dengan menggunakan pengujian 
perubahan akrual. Perry dan Williams (1994), mengindikasi bahwa unexpected accruals adalah negatif (income-decreasing) sebelum management buyout.

Pada periode equity offer, manajer perusahaan banyak melakukan overstate laba. Temuan-temuan yang ada mengindikasi bahwa perusahaan melaporkan positive (income-increasing) unexpected accruals sebelum seasoned equity offers (Teoh, Welch, dan Wong (1998b)), initial public offers (Teoh, Welch, dan Wong (1998a) serta Teoh, Wong, dan Rao (1998)), dan stock-financed acquisitions (Erickson dan Wang, 1998). Juga ditemukan bukti adanya akrual yang tak terekspektasi mengikuti initial public offers (Teoh, Wong, dan Rao) dan stock-financed acquisitions (Erickson dan Wang).

Ujiyantho dan Pramuka (2007) melakukan penelitian dengan sampel perusahaan sebanyak 30 perusahaan manufaktur yang terdaftar di BEI dari tahun 2002-2004. Hasil dari penelitian ini adalah kepemilikan manajerial berpengaruh negatif signifikan terhadap earnings management dan proporsi dewan komisaris independen berpengaruh positif signifikan terhadap earnings management.

$$
\text { Susilowati (2010) menguji }
$$

pengaruh governansi perusahaan pada managemen laba membuktikan bahwa governansi korporasi berpengaruh negatif terhadap earnings management. Sampel berjumlah 35 perusahaan nonkeuangan yang listing di BEI dengan 5 tahun pengamatan mulai tahun 2003 sampai tahun 2007. Hasil penelitian menunjukkan hanya faktor komite audit berpengaruh signifikan terhadap earning management.

Ulfah (2006) menguji jumlah dewan direksi, leverage, dan persentase saham yang ditawarkan kepada publik saat IPO. Hasil dari penelitian ini menunjukkan bahwa hanya leverage yang berpengaruh signifikan terhadap earnings management. Sedangkan faktor-faktor yang lain tidak berpengaruh secara signifikan terhadap earnings management. Sampel penelitian yang digunakan sejumlah 21 perusahaan tekstil yang go publik di BEI pada tahun 2001-2004. 


\section{METODE PENELITIAN}

\subsection{Variabel Penelitian dan Definisi Operasional}

Variabel independent penelitian ini adalah mekanisme governansi korporasi. Corporate governace merupakan upaya yang dilakukan oleh semua pihak yang berkepentingan dengan perusahaan untuk menjalankan usahanya secara baik sesuai dengan hak dan kewajibannya masing-masing (Susilowati, 2010). Mekanisme governansi korporasi dalam penelitian ini antara lain : (1) Kepemilikan Manajerial, (2) Kepemilikan Institusional, (3) Proporsi Dewan Komisaris Independen, (4) Ukuran Dewan Komisaris, dan (5) Keberadaan Komite Audit.

\subsubsection{Kepemilikan Manajerial}

Kepemilikan manajerial dapat diartikan sebagai jumlah persentase saham yang dimiliki manajer dan direktur perusahaan pada akhir tahun untuk masing-masing periode pengamatan. Apabila kepemilikan saham manajerial tinggi, maka kemungkinan terjadinya perilaku opportunistic manajer (earnings management) akan menurun. Dalam penelitian ini kepemilikan manajerial diukur dengan persentase jumlah saham yang dimiliki pihak manajemen dari seluruh modal saham perusahaan yang beredar (board of directors).

\subsubsection{Kepemilikan Institusional}

Kepemilikan institusional adalah jumlah kepemilikan saham yang dimiliki oleh pihak institusi. Kepemilikan institusional yang tinggi dapat menggantikan atau memperkuat fungsi monitoring dan dewan komisaris oleh perusahaan. Hal ini dikarenakan kepemilikan oleh investor institusional merupakan mekanisme alternatif dalam governansi korporasi (Warhani, 2008). Investor institusional mencakup bank, dana pensiun, perusahaan asuransi, dan lembaga keuangan lainnya. Dalam penelitian ini kepemilikan institusional diukur dengan menggunakan persentase jumlah saham yang dimiliki institusi dari seluruh modal saham yang beredar.

\subsubsection{Komisaris Independen}

Board of director dari pihak independen dapat lebih efektif dalam melakukan pengawasan (Klein, 2002 dalam Murhadi, 2009: 2). Hal ini diperkuat dengan pernyataan kinerja operasi dan stock return bertambah baik 
dengan semakin meningkatnya

komisaris independen (Cornett et.al., 2008 dalam Murhadi, 2009: 2). Peran dewan komisaris independen dapat meningkatkan kualitas laba dengan membatasi tingkat manajemen laba melalui fungsi monitoring atas pelaporan keuangan. Fungsi monitoring yang dilakukan oleh dewan komisaris dipengaruhi oleh jumlah atau ukuran dewan komisaris.

$\begin{array}{ccr}\text { Proporsi } & \text { dewan } & \text { komisaris } \\ \text { independen } & \text { diukur } & \text { dengan }\end{array}$
menggunakan indikator persentase anggota dewan komisaris yang berasal dari luar perusahaan dari seluruh ukuran anggota dewan komisaris perusahaan. Sedangkan ukuran dewan komisaris diukur dengan menggunakan indikator jumlah anggota dewan komisaris suatu perusahaan.

\subsubsection{Keberadaan Komite Audit}

Komite audit adalah komite yang dibentuk oleh dewan komisaris untuk melakukan tugas pengawasan pengelolaan perusahaan. Keberadaan Komite Audit dalam penelitian ini diukur dengan menggunakan variabel dummy, yaitu apabila suatu perusahaan mempunyai komite audit maka diberi angka 1 dan apabila suatu perusahaan tidak mempunyai komite audit maka diberi angka 0 .

\subsubsection{Manajemen Laba}

Variabel dependent merupakan variabel yang dipengaruhi oleh variabel lain dan terikat. Dalam penelitian ini adalah earnings management. Dechow et al. (dalam Ujiantho dan Pramuka, 2007) menyebutkan bahwa penggunaan discretionary accruals sebagai proksi manajemen laba dihitung dengan menggunakan Modified Jones Model karena model ini dianggap lebih baik di antara model lain untuk mengukur manajemen laba.

$\mathrm{TA}=\mathrm{N}_{\mathrm{it}}-\mathrm{CFO}_{\mathrm{it}}$

Nilai total accrual (TA) yang diestimasi dengan persaman regresi OLS sebagai berikut:

$\mathrm{TA}_{\mathrm{it}} / \mathrm{A}_{\mathrm{it}-1}=\beta_{1}\left(1 / \mathrm{A}_{\mathrm{it}-1}\right)+\beta_{2}\left(\Delta \operatorname{Rev}_{\mathrm{t}} /\right.$ $\left.\mathrm{A}_{\mathrm{it}-1}\right)+\beta_{3}\left(\mathrm{PPE}_{\mathrm{t}} / \mathrm{A}_{\mathrm{it}-1}\right)+\mathrm{e}$

Dengan menggunakan koefisien regresi di atas nilai non discretionary accruals (NDA) dapat dihitung dengan rumus :

$\mathrm{NDA}_{\mathrm{it}}=\beta_{1}\left(1 / \mathrm{A}_{\mathrm{it}-1}\right)+\beta_{2}\left(\Delta \mathrm{Rev}_{\mathrm{t}} / \mathrm{A}_{\mathrm{it}-1}-\right.$ $\left.\Delta \operatorname{Rec}_{t} / A_{\text {it- } 1}\right)+\beta_{3}\left(P E_{t} / A_{\text {it }-1}\right)$ 
Selanjutnya discretionary accrual (DA)

dapat dihitung sebagai berikut:

$\mathrm{DA}_{\mathrm{it}}=\mathrm{TA}_{\mathrm{it}} / \mathrm{A}_{\mathrm{it}-1}-\mathrm{NDA}_{\mathrm{it}}$

Keterangan :

DA $_{\mathrm{it}}=$ Discretionary Accruals perusahaan i pada periode ke $\mathrm{t}$

$\mathrm{NDA}_{\mathrm{it}}=$ Non Discretionary Accruals perusahaan i pada periode ke $\mathrm{t}$

$\mathrm{TA}_{\mathrm{it}}=$ Total akrual perusahaan $\mathrm{i}$ pada periode ke $\mathrm{t}$

$\mathrm{N}_{\mathrm{it}} \quad=$ Laba bersih perusahaan $\mathrm{i}$ pada periode ke-t

$\mathrm{CFO}_{\text {it }}=$ Aliran kas dari aktivitas operasi perusahaan i pada periode ke $\mathrm{t}$

$\mathrm{A}_{\mathrm{it}-1}=$ Total aktiva perusahaan $\mathrm{i}$ pada periode ke $\mathrm{t}-1$

$\Delta \operatorname{Rev}_{\mathrm{t}}=$ Perubahan pendapatan perusahaan i pada periode ke $\mathrm{t}$

$\mathrm{PPE}_{\mathrm{t}}=$ Aktiva tetap perusahaan pada periode ke $\mathrm{t}$

$\Delta \operatorname{rec}_{\mathrm{t}}=$ Perubahan piutang perusahaan i pada periode ke $\mathrm{t}$

e $=$ Error

DA digunakan sebagai proksi manajemen laba.

\subsection{Populasi dan Sampel}

Populasi dalam penelitian ini adalah laporan keuangan perusahaan manufaktur yang terdaftar di Bursa Efek Indonesia. Alasan peneliti memilih perusahaan manufaktur sebagai objek penelitian, hal ini disebabkan perusahaan manufaktur yang terdaftar di BEI terdiri dari berbagai sub sektor industri sehingga dapat mencerminkan rekasi pasar modal secara keseluruhan. Metode pengambilan sampel dilakukan dengan menggunakan metode purposive sampling dengan kriteria-kriteria sebagai berikut :

1. Perusahaan manufaktur yang telah listing di Bursa Efek Indonesia tahun 2015-2017.

2. Perusahaan yang menerbitkan laporan tahunan (annual report) yang berakhir pada tanggal 31 Desember selama periode pengamatan 2015, 2016, dan 2017. Proses pengambilan dilakukan secara purposive.

3. Perusahaan yang memiliki data mengenai Dewan Komisaris Independen, Ukuran Dewan Komisaris Independen, Kepemilikan Institusional, Kepemilikan Manajerial dan Komite Audit.

4. Perusahaan yang menyajikan laporan keuangan dalam bentuk rupiah. 
Periode dalam penelitian ini dibatasi antara tahun 2015 sampai 2017 dengan harapan akan diperoleh akurasi hasil penelitian. Data time series sebanyak tiga tahun sedangkan data antar ruang (croos section) diambil dari seluruh perusahaan manufaktur yang telah terdaftar di Bursa Efek Indonesia, kecuali perusahaan perbankan dan perusahaan asuransi, serta perusahaan yang memenuhi kriteria di atas. Perusahaan perbankan dan asuransi dalam penelitian ini tidak dijadikan sampel karena adanya predominance asset (aset dominan) pada neraca, selain itu jalur normal dari bisnis perusahaan keuangan adalah menghubungkan antara unit surplus dan unit defisit.

\subsection{Metode Analisis}

Metode analisis data yang digunakan dalam penelitian ini adalah analisis kuantitatif. Analisis kuantitatif adalah bentuk analisa yang menggunakan angka-angka dan dengan perhitungan statistik untuk menganalisis suatu hipotesis dan memerlukan beberapa alat analisis.

Teknik analisis statistika yang digunakan dalam penelitian ini adalah statistik deskriptif dan regresi berganda.
Analisis regresi berganda digunakan untuk menguji pengaruh dari beberapa variabel bebas terhadap satu variabel terikat. Analisis regresi dapat memberikan jawaban mengenai besarnya pengaruh setiap variabel independent terhadap variabel dependent-nya. Dalam penelitian ini model regresi berganda yang akan dikembangkan untuk menguji pengaruh mekanisme governansi korporasi terhadap manajemen laba (H1a, H2a, H3a, H4a, dan H5a) adalah sebagai berikut :

$\mathrm{ML}=\beta_{0}-\beta_{1} \mathrm{KI}-\beta_{2} \mathrm{KM}-\beta_{3} \mathrm{PDKI}+$ $\beta_{4} \mathrm{UDK}-\beta_{5} \mathrm{KKA}+\mathrm{e}$

dengan

ML = Manajemen Laba

KI = Kepemilikan Institusional

$\mathrm{KM}=$ Kepemilikan Manajerial

PDKI = Proporsi dewan

komisaris independen

UDK = Ukuran dewan komisaris

KKA $=$ Keberadaan Komite

Audit

$\beta_{0} \quad=$ Konstanta

$\beta=$ Koefisien regresi

e $\quad=$ Error 


\section{HASIL DAN PEMBAHASAN}

\subsection{Populasi dan Sampel}

Populasi penelitian adalah perusahaan manufaktur yang terdaftar di BEI mulai tahun 2015-2017. Pengambilan sampel dilakukan dengan metode purposive sampling. Data penelitian mengenai nama-nama perusahaan manufaktur yang terdaftar di BEI tahun 2015-2017 di dapat dari www.idx.co.id Berdasarkan perhitungan tersebut diperoleh jumlah sampel sebanyak 37 perusahaan yang memenuhi kriteria yang ditentukan. Data firmyears untuk 3 tahun penelitian menghasilkan jumlah observasi 111 data.

\subsection{Hasil Pengujian Hipotesis}

Sebelum melakukan pengujian pengaruh setiap variabel independen terhadap variabel dependen, terlebih dahulu dilakukan pengujian model regresi dengan menggunakan uji $\mathrm{F}$ (ANOVA). Berikut hasil uji $\mathrm{F}$ dari setiap model regresi dalam penelitian ini :

Tabel 4.1

Pengujian Model Regresi 1 ANOVA $^{b}$

\begin{tabular}{|c|c|c|c|}
\hline Sum of Squares & $\mathrm{df}$ & Mean Square & Ferpengadigh terhadap manajemen laba. \\
\hline Regression & 174 & 4 & $.699^{\mathrm{a}^{2}}$ \\
\hline Residual & 8.391 & 106 & Hopotesis yang menyatakan keberadaa \\
\hline Total & 8.565 & 110 & \\
\hline
\end{tabular}

Pengujian regresi menunjukkan nilai $\mathrm{F}$ sebesar 0,551 dengan tingkat signifikansi sebesar 0,699. Tingkat signifikansi lebih besar dari 0,05, maka menununjukkan semua koefisien regresi variabel independen dalam penelitian bernilai 0 atau dengan kata lain tidak ada variabel independen yang mempunyai pengaruh terhadap variabel dependen yaitu manajemen laba. Sehingga tidak perlu dilihat hasil uji t. Semua hipotesis yang menyatakan kepemilikan manajerial, kepemilikan institusional, proporsi dewan komisaris independen, dan ukuran dewan komisaris berpengaruh terhadap manajemen laba ditolak.

Variabel keberadaan komite audit telah dikeluarkan dalam analisis regresi karena nilai variabel dummy yang konstan. Hal tersebut mengindikasikan bahwa semua perusahaan yang dijadikan sampel dalam penelitian ini telah memiliki komite audit, interpretasinya adalah keberadaan komite audit tidak terhadap nilai perusahaan ditolak. 


\subsection{Pembahasan}

Hasil pengujian menunjukkan bahwa variabel mekanisme governansi korporasi pada penelitian ini yaitu kepemilikan manajerial, kepemilikan institusional, proporsi dewan komisaris independen, ukuran dewan komisaris, dan keberadaan komite audit semuanya tidak berpengaruh terhadap manajemen laba.

\subsubsection{Pengaruh}

Manajerial

Kepemilikan

terhadap

\section{Manajemen Laba}

Hasil regresi menunjukkan bahwa variabel kepemilikan manajerial tidak berpengaruh terhadap manajemen laba. Hasil ini tidak mendukung penelitian yang dilakukan Ujiantho dan Pramuka (2007) dan Pranata dan Mas'ud (2003) yang menyatakan bahwa kepemilikan manajerial berpengaruh negatif signifikan terhadap manajemen laba. Hal ini dapat dijelaskan karena saham yang dimiliki oleh manajerial tidak terlalu signifikan dalam perusahaan.

Bukti observasi

data memperlihatkan bahwa rata-rata perusahaan sampel yang memiliki kepemilikan manajerial hanya $0,3 \%$. Bahkan masih banyak perusahaan yang tidak memiliki kepemilikan manajerial. Hal tersebut menyebabkan kepemilikan manajerial tidak berpengaruh terhadap manajemen laba.

Hasil penelitian ini sesuai dengan pendapat yang dikemukakan oleh Gabrielsen et al (2002) menguji hubungan antara kepemilikan manajerial dan kandungan informasi laba serta discretionary accrual. Dengan menggunakan data pasar modal Denmark ditemukan adanya hubungan yang positif tetapi tidak signifikan antara kepemilikan manajerial dan discretionary accrual. Terlebih lagi penerapan governansi korporasi yang baik merupakan hal yang termasuk baru di Indonesia sehingga penerapannya belum dapat dilaksanakan secara optimal oleh masing-masing perusahaan. Dapat dikatakan pengaruhnya masih sangat kecil untuk mempengaruhi manajemen laba.

\subsubsection{Pengaruh}

Kepemilikan

Institusional

terhadap

\section{Manajemen Laba}

Hasil pengujian regresi menunjukkan bahwa variabel kepemilikan institusional tidak berpengaruh terhadap manajemen laba. Hal ini bertentangan dengan pengujian 
yang dilakukan Suranta dan Midiastuty (2005), Jensen dan Meckling (1976) ,Warfield et al., (1995), Dhaliwal et al., (1982), Morck et al., (1988) dan Pranata dan Mas'ud (2003) dalam Siallagan dan Machfoedz (2006) yang menemukan adanya pengaruh negatif signifikan. Namun hal ini mendukung penelitian yang dilakukan oleh Ujiantho dan Pramuka (2007), Selain itu pandangan atau konsep dari Porter (dalam Pranata dan Mas'ud 2003) juga mengatakan bahwa institusional adalah pemilik yang lebih memfokuskan pada current earnings. Akibatnya manajer terpaksa untuk melakukan tindakan yang dapat meningkatkan laba jangka pendek, misalnya dengan melakukan manipulasi laba. Pandangan yang sama juga dikemukakan oleh Cornett et al. (dalam Ujiantho dan Pramuka, 2007) yang menyatakan bahwa kepemilikan institusional akan membuat manajer merasa terikat untuk memenuhi target laba dari para investor, sehingga mereka akan tetap cenderung terlibat dalam tindakan manipulasi laba.

\subsubsection{Pengaruh Proporsi Dewan}

Komisaris Independen terhadap

\section{Manajemen Laba}

Hasil pengujian regresi menunjukkan bahwa proporsi dewan komisaris independen tidak berpengaruh terhadap manajemen laba dengan tingkat signifikansi sebesar 0,5\%. Hasil penelitian ini mendukung penelitian dari Ujiantho dan Pramuka (2007) dan Sefiana (2008) yang menyatakan bahwa proporsi dewan komisaris independen tidak berpengaruh terhadap manajemen laba. Hal ini dapat dijelaskan bahwa penempatan atau penambahan anggota dewan komisaris independen dimungkinkan hanya sekedar memenuhi ketentuan formal, sementara pemegang saham mayoritas (pengendali/founders) masih memegang peranan penting sehingga kinerja dewan tidak meningkat bahkan turun (Gideon, 2005). Sylvia dan Siddharta (2005) dalam Ujiantho dan Pramuka (2007) juga menyatakan bahwa pengangkatan dewan komisaris independen oleh perusahaan mungkin hanya dilakukan untuk pemenuhan regulasi saja tapi tidak dimaksudkan untuk menegakkan Good Corporate Governance (GCG) di dalam perusahaan. Terbukti bahwa rata-rata 
proporsi dewan komisaris independen perusahaan sampel sebesar $37,8 \%$ yang mengindikasikan bahwa sebagian besar perusahaan sampel telah memenuhi standar BAPEPAM yaitu minimal dewan komisaris independen adalah $30 \%$. Kondisi ini juga ditegaskan dari hasil survei Asian Development Bank dalam Gideon (2005) yang menyatakan bahwa kuatnya kendali pendiri perusahaan dan kepemilikan saham mayoritas menjadikan dewan komisaris tidak independen. Fungsi pengawasan yang seharusnya menjadi tanggungjawab anggota dewan menjadi tidak efektif.

\subsubsection{Pengaruh Ukuran Dewan}

Komisaris terhadap Manajemen Laba

Hasil pengujian regresi menunjukkan bahwa variabel ukuran dewan komisaris tidak berpengaruh terhadap manajemen laba, namun secara statistika arah yang menunjukkan ke negatif mengisyaratkan bahwa fungsi kontrol yang dilakukan dewan komisaris telah dapat menurunkan manajemen laba walau tidak signifikan. Hasil ini mendukung penelitian dari Ujiantho dan Pramuka (2007), namun menentang penelitian yang dilakukan Murwanigsari
(2008), Dechow et al.,(1996), Klein (2002), Chtourou et al., (2001), Xie et al., (2003), Pranata dan Mas'ud (2003) dan Cornett et al., (2006) dalam Ujiantho dan Pramuka (2007). Hal ini dapat dijelaskan bahwa ukuran besar kecilnya anggota dewan komisaris telah dapat menjadi salah satu faktor penentu keefektifan pengawasan dalam pengelolaan manajemen perusahaan walau tidak secara signifikan. Akan tetapi efektifitas mekanisme pengendalian tergantung pada nilai, norma dan kepercayaan yang diterima dalam suatu organisasi (Jennings 2004a; 2004b; 2005a; Oliver, 2004 dalam Ujiantho dan Pramuka, 2007).

\subsubsection{Pengaruh Keberadaan Komite Audit terhadap Manajemen Laba}

Hasil pengujian regresi menunjukkan bahwa variabel keberadaan komite audit telah dikeluarkan dalam pengujian secara statistik, karena nilai dari keberadaan komite audit konstan yaitu 1. Hal ini mengindikasikan bahwa seluruh perusahaan sampel dalam penelitian telah mempunyai komite audit. Implikasinya adalah keberadaan komite audit bukan merupakan mekanisme 
governansi korporasi yang dapat mempengaruhi manajemen laba. Hasil ini menentang penelitian yang dilakukan oleh Siallagan dan Mas'ud (2006) dan Murwaningsari (2008) yang menyatakan bahwa komite audit berpengaruh negatif terhadap manajemen laba, namun mendukung penelitian dari Sefiana (2008). Hal ini dapat dijelaskan bahwa karena dalam penelitian ini seluruh perusahaan sampel telah memiliki komite audit sehingga secara matematis seberapa besar koefisien regresi komite audit dikalikan dengan 1 maka tidak akan berpengaruh terhadap manajemen laba.

\section{KESIMPULAN, KETERBATASAN DAN SARAN}

\subsection{Kesimpulan}

Penelitian ini bertujuan untuk mengetahui dan menganalisis pengaruh mekanisme governansi korporasi terhadap manajemen laba. Berdasarkan hasil penelitian didapatkan kesimpulan bahwa mekanisme governansi korporasi yang terdiri dari kepemilikan manajerial, kepemilikan institusional, proporsi dewan komisaris independen, ukuran dewan komisaris, dan keberadaan komite audit tidak berpengaruh terhadap earning management.

\subsection{Keterbatasan Penelitian}

Beberapa keterbatasan dalam

penelitian ini antara lain :

1. Variabel keberadaan komite audit tidak dapat masuk dalam pengujian regresi karena seluruh perusahaan sampel telah mempunyai komite audit, namun belum diteliti pengaruh karakteristik komite audit terhadap manajemen laba ataupun nilai perusahaan sebagai variabel utama dalam penelitian

2. Dalam laporan keuangan tahunan perusahaan, hanya sedikit menyajikan pemegang sahamnya, sehingga terdapat kesulitan dalam mendeteksi variabel kepemilikan institusional secara tepat

3. Sampai saat ini belum ada satu penelitian pun yang berhasil mengidentifikasi model perhitungan manajemen laba mana yang lebih superior dibandingkan dengan model lainnya.

\subsection{Saran}

Dengan adanya keterbatasan dalam penelitian ini, adapun saran yang dapat disampaikan adalah :

1. Diharapkan untuk penelitian yang serupa untuk menambahkan mekanisme governansi korporasi 
ataupun variabel-variabel lain yang memungkinkan mempunyai pengaruh terhadap manajemen laba atau nilai perusahaan seperti karakteristik komite audit, klasifikasi akuntan publik, ataupun CEO duality.

2. Disarankan untuk mencari sumber lain yang relevan untuk menentukan

\section{DAFTAR PUSTAKA}

Assih, P., dan Gudono. 2005. Hubungan tindakan perataan penghasilan dengan reaksi pasar atas pengumuman informasi laba perusahaan yang terdapat di Bursa Efek Jakarta, Jurnal Riset Akuntansi Indonesia, Vol 3 No, 1. (Januari ): $35-53$

BAPEPAM. 2002. Peraturan No. X. K. II. Kep.17/PM/2002.

Cornett M. M, J. Marcuss, Saunders dan Tehranian H.. 2006. Earnings Management, Corporate Governance, and True Financial Performance.

http://papers.ssrn.com.

DeAngelo, L, E., 1988. Managerial competition, information costs, and corporate governance: The use of accounting performance measures in proxy contests. Journal of Accounting and Economics, 12: 3-36.

Ericson, R.H., B. Wang, 1998. An empirical test of politically-motivated income smoothing in the oil refining industry. Journal of Applied persentase kepemilikan institusional agar data lebih valid

3. Disarankan menggunakan model untuk menghitung discretionary acrrual yang lainnya agar dapat diketahui perbedaannya, serta dapat memilih model mana yang paling mendekati baik untuk keperluan penelitian. Business Research 10(1)
(Winter): 92.

Effendi, M. Arief, 2005. Peranan Komite Audit dalam Meningkatkan Kinerja Perusahaan.Jurnal Akuntansi Pemerintah, Volume 1, No. 1. Jakarta.

FCGI. 2008. Corporate Governance Suatu Pengantar: Peranan Dewan Komisaris dan Komite Audit Dalam Pelaksanaan Corporate Governance.

Faisal. 2005. Analisis Agency Cost, Struktur Kepemilikan dan Mekanisme Corporate Governance. Simposium Nasional VII, Ikatan Akuntansi Indonesia.

Gideon SB Boediono. 2005. Kualitas Laba: Studi Pengaruh Mekanisme Corporate Governace dan Dampak Manajemen Laba dengan Menggunakan Analisis Jalur. Simposium Nasional Akuntansi VIII, IAI, 2005. 
Haryono, Slamet. 2005. Struktur Kepemilikan dalam Bingkai Teori Keagenan. Jurnal Akuntansi dan Bisnis Vol.5, No.1: 63-71.

Herawaty, Vinola. 2008. Peran Praktik Corporate Governance Sebagai Moderating Variable dari Pengaruh Earnings Management Terhadap Nilai Perusahaan. Jurnal Akuntansi dan Keuangan, Vol.10, No.2: 97-108

Kaihatu, Thomas S.. 2006. Good Corporate Governance dan Penerapannya di Indonesia. Jurnal Manajemen dan Kewirausahaan, Vol.8, no. 1, maret 2006: 1-9.

Lastanti, S, Hexana. 2005. Hubungan Struktur Corporate Governance dengan Kinerja Perusahaan dan Reaksi Pasar. Prosiding Konvensi Nasional Akuntansi IV. Jakarta.

Lo, Kin, 2007. Earning Management and Earning Quality, Journal of Accounting and Economics, 1-8.

Murhadi, Werner R.. 2009. Studi Pengaruh Good Corporate Governance Terhadap Praktik Earnings Management pada Perusahaan Terdaftar di PT Bursa Efek Indonesia. Jurnal Managemen dan Kewirausahaan Vol. 11, No. 1: 1-10.

Palupi, Yekti. 2010. Pengaruh penerapan Prinsip-Prinsip Good Corporate Governance terhadap Kinerja Pemerintah Daerah. Skripsi: Universitas Jember.

Perry, S., M. Williams, 1998. Is institutional ownership associated with earnings management and the extent to which stock prices reflect future earnings? Working Paper.

Saiful, 2002. Hubungan Manajemen Laba (Earning Management) dengan Kinerja Operasi dan Return Saham disekitar IPO. Simposium Nasional Akuntansi 5, Semarang, 5-6 September 2002.

Setyapurnama, Yudi Santara dan Norpratiwi, A.M. Vianey. 2005. Pengaruh Corporate Governance Terhadap Peringkat Obligasi dan Yield Obligasi.

Siallagan, Hamonangan dan Machfoedz, Mas'ud. 2006. Mekanisme Corporate Governance, Kualitas Laba Dan Nilai Perusahaan. Simposium Nasional Akuntansi 9 Padang. Hal. 1-23.

Siregar, Sylvia. Veronica N.P, dan Utama, Siddharta. 2006 Pengaruh Struktur Kepemihkan, Ukuran Perusahaan, dan Praktik Corporate Governance terhadap Pengelolaan Laba (Earnings Management), Journal Riset Akuntansi Indonesia, Vol. 9 No.3.haL 307-326.

Susilowati, Retno Yuni Nur. 2010. Pengaruh Governansi Perusahaan pada Managemen Laba: Studi Empiris Perusahaan Nonkeuangan di BEI. Jurnal Akuntansi dan Keuangan Vol. 15, No.2.

Teoh, S.H., I. Welch, dan T.J. Wong. 1998. Earnings management and the underperformance of seasoned equity offerings. Journal of Financial Economics, 50: 63-99. 
Ujiyantho, Muh. Arief dan Pramuka, Bambang Agus. 2007. Mekanisme corporate governance, manajemen laba dan kinerja keuangan. Simposium Nasional Akuntansi $\mathrm{x}$ unhas makassar 26-28 juli, 2007: 1-26.

Ulfah, Yana. 2006. Analisis Faktor-faktor Mempengaruhi yang Earnings
Management Perusahaan Tekstil yang Go Publik di Bursa Efek Jakarta. Manajemen Akuntansi dan Bisnis Volume 5, Nomor 1.

Yushita, Amanita Novi. 2010. Earnings Management dalam Hubungan Keagenan. Jurnal Pendidikan Akuntansi Indonesia Vol.VIII.No.1., 53-62. 